\title{
Analytical approaches for Optimal Placement and sizing of Distributed generation in Power System
}

\author{
Mohit Mittal*,Rajat Kamboj**,Shivani Sehgal*** \\ *Student of Electrical \& Electronics Engg., Doon Valley Institute of Engg. \& Technology,Karnal,India. \\ **Assistant Professor,Department of EEE, Doon Valley Institute of Engg. \& Technology, Karnal,India. \\ *** Assistant Professor,Department of EEE, Doon Valley Institute of Engg. \& Technology, Karnal,India.
}

\begin{abstract}
This work proposes a new algorithm which investigates the performance of Distribution system with multiple DG sources for the reduction in the line loss, by knowing the total number of DG units that the user is interested to connect. Strategic placement of multiple DG sources for a distribution system planner is a complex combinatorial optimization problem.

The new and fast algorithm is developed for solving the power flow for radial distribution feeders taking into account embedded distribution generation sources. Also, new approximation formulas are proposed to reduce the number of required solution iterations. Power flow techniques (PF) for calculating Network performance index (NPI), Genetic algorithm in search of best locations, with considering NPI as fitness function.
\end{abstract}

\section{INTRODUCTION}

The impact of DG in system operating characteristics, such as electric losses, voltage profile, stability and reliability needs to be appropriately evaluated. The problem of DG allocation and sizing is of great importance. The installation of DG units at non-optimal places can result in an increase in system losses, implying in an increase in costs and thereof having an effect of opposite to the desired. For that reason the use of an optimization method capable of indicating the best solution for a given distribution network can be very useful for the system planning engineer when dealing with the increase of DG penetration that is happening nowadays.

\section{System Description}

\section{MATHEMATICAL FORMULATION}

Consider a three-phase, balanced radial distribution feeder with $\mathrm{n}$ buses, $I$ laterals and sublatera generations. Also, $n \mathrm{DG}$ distributed and $n \mathrm{C}$ shunt capacitors as shown in figure 331ls.

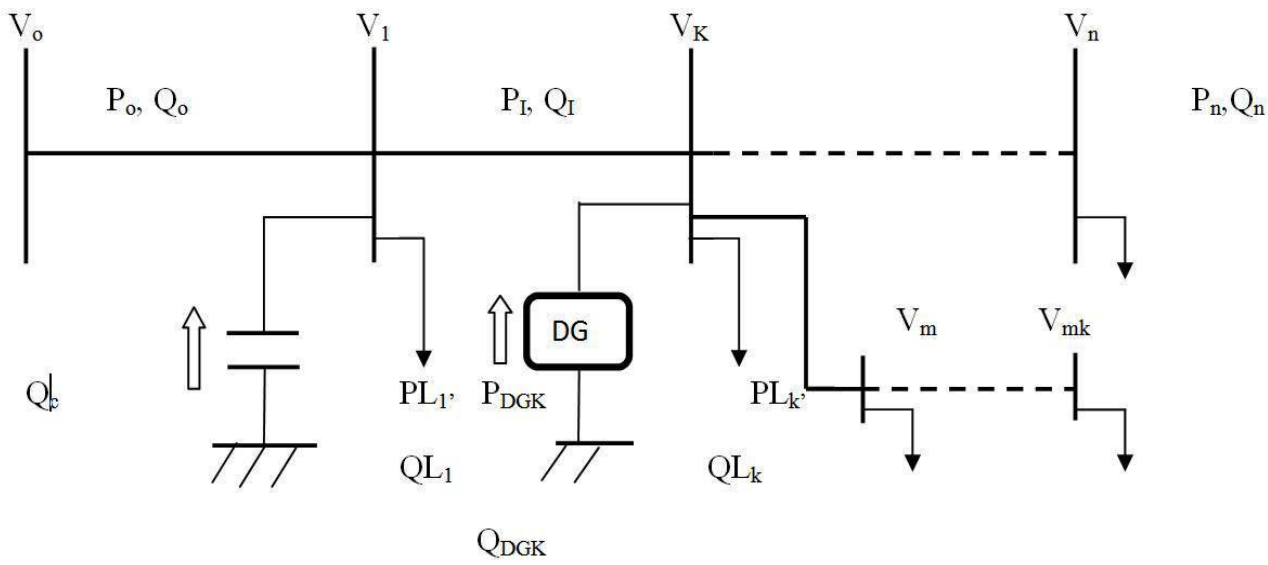

Fig. 1 : Redial Distribution feeder model including DG and Capacitor

The three recursive branch power flow equations are:

$$
\begin{aligned}
& \mathrm{P}_{\mathrm{i}+1}=\mathrm{P}_{\mathrm{i}}-\mathrm{r}_{\mathrm{i}+1}\left(\mathrm{P}_{\mathrm{i}}^{2}+\mathrm{Q}_{\mathrm{i}}^{2}\right) / \mathrm{V}_{\mathrm{i}}^{2}-\mathrm{P}_{\mathrm{Li}+1}+\mu_{\mathrm{p}} \mathrm{AP}_{\mathrm{i}+1} \\
& \mathrm{Q}_{\mathrm{i}+1}=\mathrm{Q}_{\mathrm{i}}-\mathrm{x}_{\mathrm{i}+1}\left(\mathrm{P}_{\mathrm{i}}^{2}+\mathrm{Q}_{\mathrm{i}}^{2}\right) / \mathrm{V}_{\mathrm{i}}^{2}-\mathrm{Q}_{\mathrm{Li+1}}+\mu_{\mathrm{p}} \mathrm{AQ}_{\mathrm{i}+1} \\
& \text { www.iosrjournals.org }
\end{aligned}
$$




$$
\mathrm{V} 2 \mathrm{i+1}=\mathrm{V}_{\mathrm{i}}^{2-} 2\left(\mathrm{r}_{\mathrm{i}+1} \mathrm{P}_{\mathrm{i}}+\mathrm{x}_{\mathrm{i}+1} \mathrm{Q}_{\mathrm{i}}\right)+\left(\mathrm{r}_{\mathrm{i}+1}^{2}+\mathrm{x}^{2}{ }_{\mathrm{i}+1}\right) \mathrm{x}\left(\mathrm{P}^{2}{ }_{\mathrm{i}}+\mathrm{Q}_{\mathrm{i}}^{2}\right) / \mathrm{V}_{\mathrm{i}}{ }^{2}
$$

The following terminal conditions should be satisfied [6]:

i. $\quad$ At the end of the main feeder, laterals and sublaterals as shown in fig.2.1:

$$
\begin{aligned}
& P_{n}=Q_{n}=0 \\
& P_{k m}=Q_{k m}=0
\end{aligned}
$$

ii. The voltage at bus $\mathrm{k}$ is the same voltage of its lateral i.e:

$$
\mathrm{V}_{\mathrm{k}}=\mathrm{V}_{\mathrm{k} 0}
$$

The real and reactive power losses of each section connecting two buses are:

$$
\begin{aligned}
& \mathrm{P}_{\text {lossi }+1}=\left(\mathrm{P}_{\mathrm{i}}^{2}+\mathrm{Q}_{\mathrm{i}}{ }^{2} / \mathrm{V}_{\mathrm{i}}{ }^{2}\right) \mathrm{r}_{\mathrm{i}+1} \\
& \mathrm{Q}_{\text {lossi }+1}=\left(\mathrm{P}_{\mathrm{i}}^{2}+\mathrm{Q}_{\mathrm{i}} 2 / \mathrm{V}_{\mathrm{i}}^{2}\right) \mathrm{x}_{\mathrm{i}+1}
\end{aligned}
$$

\section{DG SIZING ISSUES}

For single DG case, The DG optimal Size will be done by using Analytical Method based on Exact Loss Formula.

The real power loss in a system is given by

$$
{ }^{N} P_{L}^{N}-\sum \sum\left[x_{i j-1}\left(P_{i} P j+Q_{i} Q j\right)+\beta_{i j}\left(Q_{i} P_{i}-P j Q j\right)\right]
$$

Where

$$
\begin{aligned}
& \mathrm{X}_{\mathrm{ij}}=\frac{r g}{V i V i} \cos (\delta \mathrm{i}-\delta \mathrm{j}), \beta=\frac{n i j}{V i V i}(\delta \mathrm{i}-\delta \mathrm{j}) \\
& \mathrm{Ri}+\mathrm{jX}_{\mathrm{ij}}=\mathrm{Z}_{\mathrm{ij}} \text { are the } \mathrm{ij}^{\text {th }} \text { element of }\left[\mathrm{Z}_{\mathrm{Bus}}\right] \text { matrix. }
\end{aligned}
$$

Analytical method is based on the fact that the power loss against injected power is a parabolic function and at minimum losses the rate of change of losses with respect to injected power becomes zero.

$$
\left.\frac{\partial \mathrm{P}_{\mathrm{L}}}{\partial \mathrm{P}_{\mathrm{i}}}=2 \sum\left(x_{i j} P_{j}-\beta_{i} \mathrm{Q}_{i}\right)=0\right)
$$

Where $\mathrm{P}_{\mathrm{i}}$ is the real power injection at node $\mathrm{I}$, which is the difference between real power generation and the real power demand at that node.

$$
\mathrm{P}_{\mathrm{i}}-\left(\mathrm{iP}_{\mathrm{DGi}} \mathrm{P}_{\mathrm{Di}}\right)
$$

Where $\mathrm{P}_{\mathrm{dgi}}$ is the real power injection from DG placed node I, and Pli is Load at node i. By combining equations results in to

$\mathrm{P}_{\text {Dgi }}-\mathrm{P}_{\mathrm{Di}}+1 / \alpha_{\mathrm{ij}}\left[\beta_{\mathrm{ij}} \mathrm{Q}_{\mathrm{i}}-\sum_{\mathrm{i}=1 \mathrm{j} \neq \mathrm{i}}^{\mathrm{N}}\right]\left(\alpha_{\mathrm{ij}} \mathrm{P}_{\mathrm{j}}-\beta_{\mathrm{ij}} \mathrm{Q}_{\mathrm{i}}\right)$

The above equation gives the optimum size of DG for each bus I, for the loss to be minimum. Any size of DG other than $P_{\text {dgi }}$ placed at bus I, will lead to higher loss. In calculating the optimum sizes of DG at various locations, using equation (2.10), it was assumed that the values of variable remain unchanged. This result in small difference between the optimum sizes obtained by this approach and repeated load flow. 


\subsection{Algorithm for Single DG case}

\section{PROPOSED ALGORITHM}

The developed algorithm is explained stepwise as follows:

Step 1: First Read the Distribution Network Data and DG size.

Step 2: Give Network Data to Power flow Algorithm to get base case power flow.

Step 3: Save base case power flow for later use.

Step 4: Calculate the Network performance for Different DG.

Step 5: Insert the DG at which the NPI value closer to unity \& optimize the DG size.

Step 6: Evaluate NPI with the help of base case power flow and Power flow with single DG inserted case.

Step 7: Print results and stop.

\subsection{Algorithm for Multiple DG}

The following Algorithm is developed with the help of New and Fast Power Flow

Solution Algorithm and Genetic Algorithm and is used to get the appropriate results. The developed algorithm is explained stepwise as follows:

Step 1: First read the Distribution Network Data.

Step 2: Give Network Data to New and Fast Powerflow Algorithm to get base case powerflow.

Step 3: Save base case powerflow for later use.

Step 4: Read Inserting Distributed Generators capacities. [Market available DG sizes 100KW, 220KW, $300 \mathrm{KW}, 500 \mathrm{KW}, 750 \mathrm{KW}, 1 \mathrm{KW}, 1.6 \mathrm{MW}]$

Step 5: Read Bus numbers for DG insertions from Genetic Algorithm. If this is first time GA will give Initial population, otherwise GA will give New Population

Step 6: Again apply powerflow for Distribution system with the inserted DG at the position from GA with the help of New and Fast powerflow Algorithm.

Step 7: Evaluate Multi Objective Index with the help of Base case powerflow and powerflow with DG inserted.

Step 8: Repeat step $6 \& 7$ for all combination of GA population.

Step 9: Check for number.

Step 10: Give NPI values as fitness values to the GA.

Step 11: With the help of fitness function values GA will do the operations (Selection, Crossover, Mutation, and Elitism) and generate new population next go to step5.

Step 12: Save the $\mathrm{n}$ best results and go to next Step

Step 13: For every best result decrease the capacity of DG with fixed $\%$ of their individual capacities and do the same for the maximum number of iterations.

Step 14: Lower limit of DG capacity will be $1 \%$ of Total load.

Step 15: Run powerflow with for all combinations of new capacities of DG and calculate NPI.

Step 16: Now compare these results with previously saved results fitness values, and print the results according to the best fitness values.

Step 17: Stop Corresponding Flowchart is as follows:

\subsection{TEST SYSTEM}

\section{CASE STUDY AND ANALYSIS}

The radial system with 33 buses and 32 branches with the total load of $3.715 \mathrm{MW}$ and $2.28 \mathrm{MVAR}$, $11 \mathrm{KV}$ is taken as test system. The single line diagram of 33bus distribution system is shown in Figure 6.1. System Data is given in appendix-B.

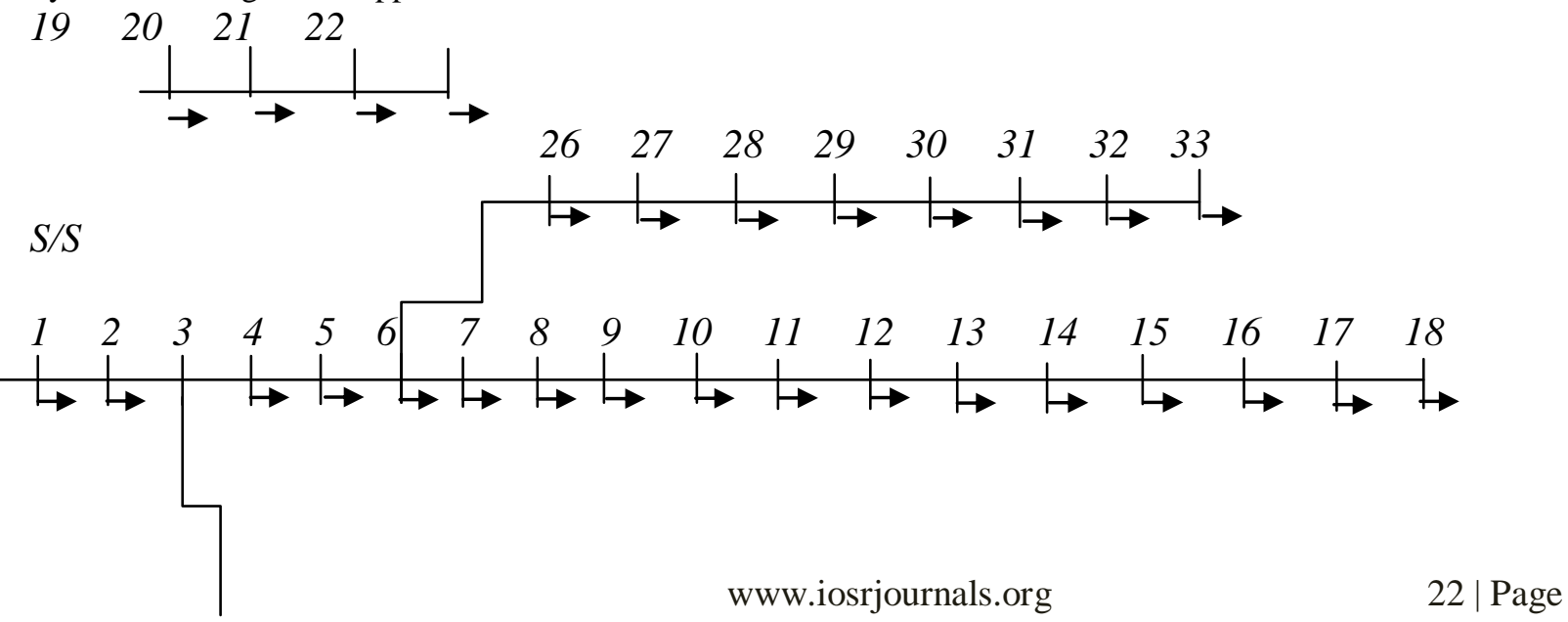




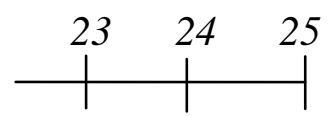

Fig.2. Single line diagram of 33 bus distribution system

\subsection{GENETIC ALGORITHM SET UP}

Representation

A Binary genetic algorithm (BGA) is employed to generate the combination of bus numbers.

Initialize Population

An initial population of size 30 is selected.

Selection

Tournament Selection is chosen for testing.

Reproduction

Two point Cross Over [0.8], [60\% to 95\% range] and Binary Mutation of ratio [0.05], [0.5\% to $1 \%$ range] is used.

\section{Generation-Elitism}

Generation Elitism is taken 5, which copies the best chromosomes into next generation.

Fitness Evaluation

The network performance index for the distribution system with DG sources is aimed to be maximum and is selected for fitness evaluation.

Termination

The algorithm stops if the number of generations reaches 300 , each simulation is a fairly lengthy process, but given that this process is a strategic one, the durations reasonable.

\subsection{RELEVANCE FACTORS OF NPI}

The NPI will numerically describe the impact of DG, considering a given location and size, on a distribution network. Close to unity values for the Network Performance Index means higher DG benefits. Table 6.0 shows the value for the relevance factors utilized in here, considering a normal operation stage analysis.

\begin{tabular}{|l|l|l|l|l|}
\hline $\mathrm{IL}_{\mathrm{p}} \mathrm{W}_{1}$ & $\mathrm{IL}_{\mathrm{Q}} \mathrm{W}_{2}$ & $\mathrm{IVD}_{\mathrm{Q}} \mathrm{W}_{3}$ & $\mathrm{IVR} \mathrm{W}$ & \\
\hline 0.33 & 0.10 & 0.15 & 0.10 & 0.32 \\
\hline
\end{tabular}

Table.1.NPI Relevance factors

\subsection{Results and analysis}

A series of simulations were run to evaluate the performance of Distribution System With a defined number of potential DG units. The capacities of DGs are considered in two ways with constant capacity and with tuned capacity. These were for the best set of 1,3 and 5 DG units located within the 32 possible sites and the corresponding Distribution system performance results.

Base case
\begin{tabular}{|l|l|l|l|l|l|l|} 
PLOAD & QLOAD & PLOSSES & QLOSSES & PUTILITY & QUTILIITY & VSI \\
\hline $3.715 \mathrm{MW}$ & $2.28 \mathrm{MVAR}$ & $210.3 \mathrm{KW}$ & $137.3 \mathrm{KVAR}$ & $3.916 \mathrm{MW}$ & $2.417 \mathrm{MVAR}$ & 0.675 \\
\hline
\end{tabular}

Table.2 Base System load flow Data

\begin{tabular}{|l|l|}
\hline Bus Number & $\begin{array}{l}\text { Voltage } \\
\text { (p.u) }\end{array}$ \\
\hline 1 & 1.0000 \\
\hline 2 & 0.9972 \\
\hline 3 & 0.9836 \\
\hline 4 & 0.9763 \\
\hline 5 & 0.9691 \\
\hline 6 & 0.9511 \\
\hline 7 & 0.9475 \\
\hline 8 & 0.9339 \\
\hline 9 & 0.9276 \\
\hline
\end{tabular}


Analytical approaches for Optimal Placement and sizing of Distributed generation in Power System

\begin{tabular}{|c|c|}
\hline 10 & 0.9217 \\
\hline 11 & 0.9208 \\
\hline 12 & 0.9193 \\
\hline 13 & 0.9132 \\
\hline 14 & 0.9109 \\
\hline 15 & 0.9095 \\
\hline 16 & 0.9088 \\
\hline 17 & 0.9067 \\
\hline 18 & 0.9067 \\
\hline 19 & 0.9061 \\
\hline 20 & 0.9967 \\
\hline 20 & 0.9931 \\
\hline 21 & 0.9924 \\
\hline 22 & 0.9918 \\
\hline 23 & 0.9801 \\
\hline 24 & 0.99734 \\
\hline 25 & 0.9701 \\
\hline 26 & 0.9491 \\
\hline 27 & 0.9466 \\
\hline 28 & 0.9351 \\
\hline 29 & 0.9269 \\
\hline 30 & 0.9234 \\
\hline 31 & 0.9192 \\
\hline 32 & 0.9183 \\
\hline 33 & 0.9180 \\
\hline
\end{tabular}

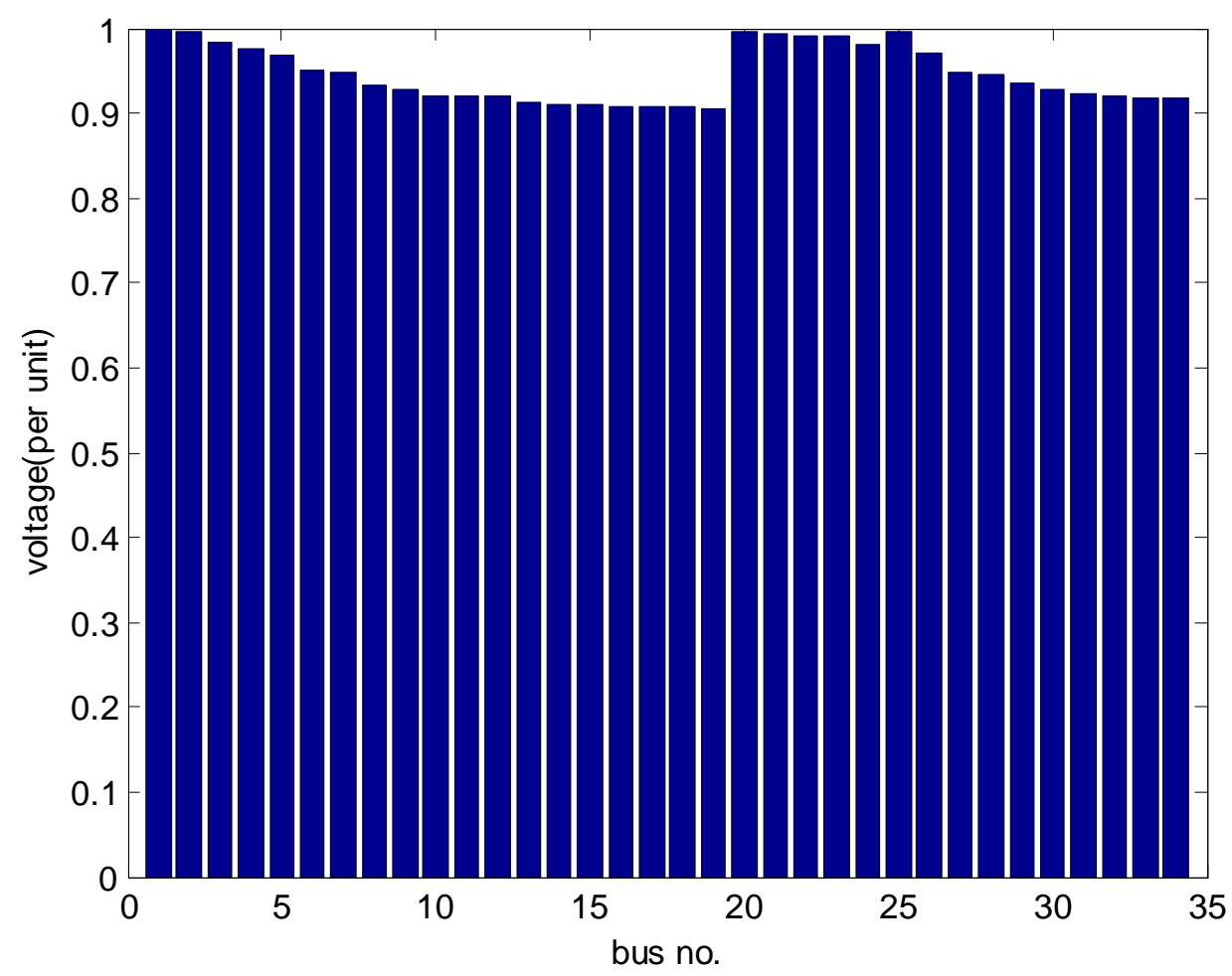

Fig. 3. Base case Voltage Profile Plot

Single DG Case

The Following table represents the IVD, IVR values for best combination IVD

IVR 
Analytical approaches for Optimal Placement and sizing of Distributed generation in Power System

\begin{tabular}{|l|l|}
\hline 0.95499 & 0.95393 \\
\hline
\end{tabular}

\begin{tabular}{|l|l|l|l|l|l|l|l|}
\hline NPI & $\begin{array}{l}\text { Bus } \\
\text { Number }\end{array}$ & $\begin{array}{l}\text { PDG } \\
(\text { KW })\end{array}$ & $\begin{array}{l}\text { P Loss } \\
(\text { KW })\end{array}$ & $\begin{array}{l}\text { Q Loss } \\
\text { KVAR })\end{array}$ & VSI & $\begin{array}{l}\text { PUTILITY } \\
(\text { KW })\end{array}$ & $\begin{array}{l}\text { QUTLITY } \\
(\text { KVAR })\end{array}$ \\
\hline 0.5489 & 31 & 1296.190 & 105.496 & 78.833 & 0.7971 & 2524.298 & 2378.832 \\
\hline 0.5477 & 32 & 1244.690 & 105.718 & 79.501 & 0.7923 & 2576.028 & 2379.506 \\
\hline 0.5411 & 33 & 1183.540 & 107.125 & 82.370 & 0.7865 & 2638.548 & 2382.369 \\
\hline 0.5328 & 30 & 1471.350 & 108.178 & 80.041 & 0.8134 & 2351.828 & 2380.041 \\
\hline 0.5331 & 6 & 1491.520 & 108.671 & 80.375 & 0.7923 & 13332.152 & 2380.376 \\
\hline
\end{tabular}

Table 2.2. Single DG Test Result with 5 best combinations

\begin{tabular}{|c|c|}
\hline Bus Number & $\begin{array}{l}\text { Voltage } \\
\text { (p.u) }\end{array}$ \\
\hline 1 & 1.0000 \\
\hline 2 & 0.9988 \\
\hline 3 & 0.9936 \\
\hline 4 & 0.9925 \\
\hline 5 & 0.9917 \\
\hline 6 & 0.9877 \\
\hline 7 & 0.9844 \\
\hline 8 & 0.9713 \\
\hline 9 & 0.9652 \\
\hline 10 & 0.9596 \\
\hline 11 & 0.9587 \\
\hline 12 & 0.9573 \\
\hline 13 & 0.9514 \\
\hline 14 & 0.9492 \\
\hline 15 & 0.9478 \\
\hline 16 & 0.9472 \\
\hline 17 & 0.9452 \\
\hline 18 & 0.9446 \\
\hline 19 & 0.9982 \\
\hline 20 & 0.9947 \\
\hline 21 & 0.9940 \\
\hline 22 & 0.9933 \\
\hline 23 & 0.9900 \\
\hline 24 & 0.9834 \\
\hline 25 & 0.9802 \\
\hline 26 & 0.9875 \\
\hline 27 & 0.9874 \\
\hline 28 & 0.9852 \\
\hline 29 & 0.9840 \\
\hline 30 & 0.9848 \\
\hline 31 & 0.9889 \\
\hline 32 & 0.9881 \\
\hline 33 & 0.9878 \\
\hline
\end{tabular}

Table 2.3 Voltage Profile with Single DG at bus 31 


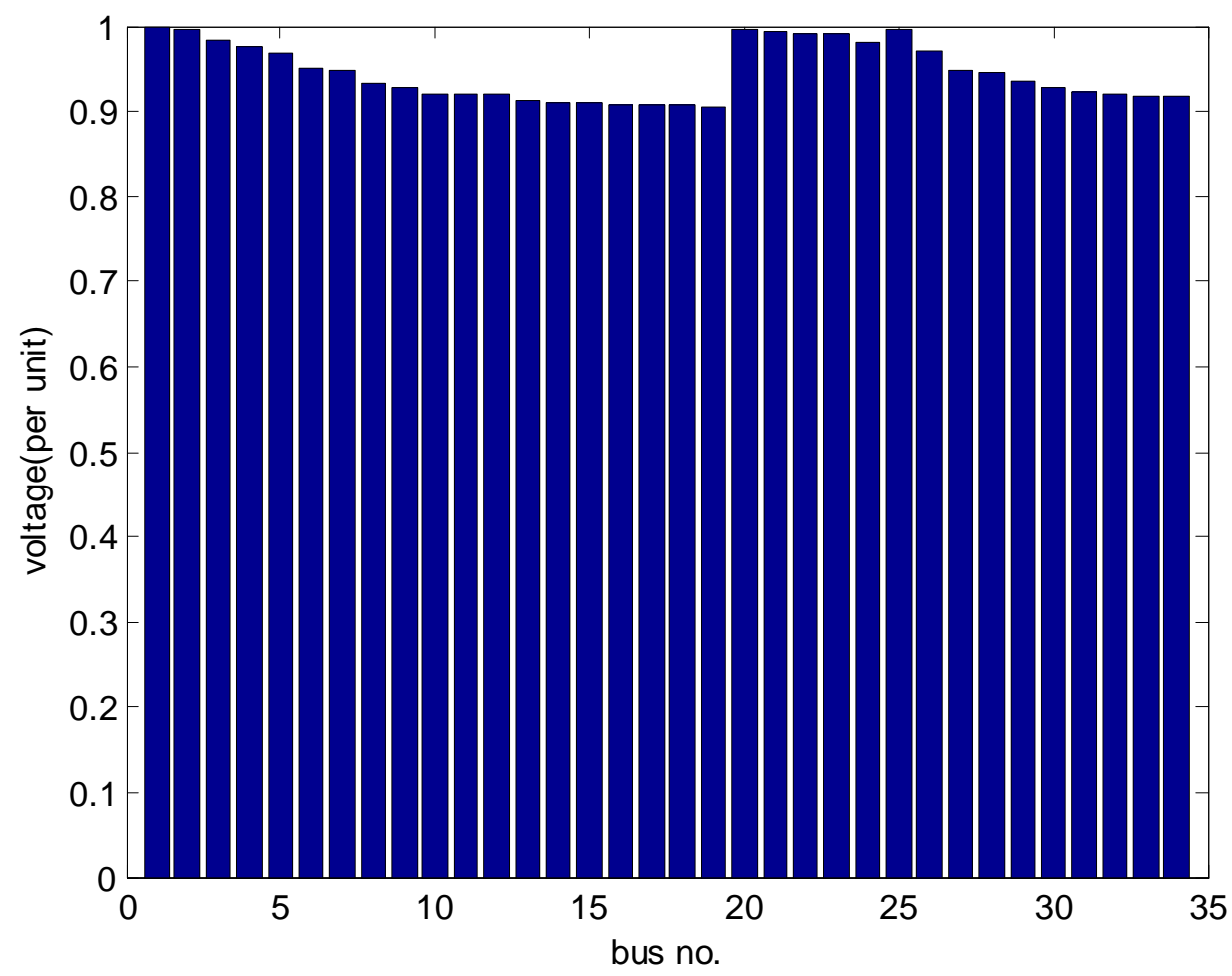

Fig.4. Voltage Profile plot with Single DG at bus 31

3DG Case

The following table represents the IVD, IVR values for best combination.

\begin{tabular}{|c|c|}
\hline IVD & IVR \\
\hline 0.9675 & 0.95657 \\
\hline
\end{tabular}

Without Tuning

\begin{tabular}{|c|c|c|c|c|c|c|c|c|}
\hline \multicolumn{9}{|c|}{ DG sizes are $1000 \mathrm{KW}, 750 \mathrm{KW}$, and $500 \mathrm{KW}$} \\
\hline NPI & $\begin{array}{l}\text { Bus } \\
\text { Number }\end{array}$ & $\begin{array}{l}\text { DG } \\
(\mathrm{KW})\end{array}$ & $\begin{array}{l}\mathrm{PD}_{\mathrm{G}} \\
\text { (Total) } \\
(\mathrm{KW})\end{array}$ & $\begin{array}{l}P_{\text {Loss }} \\
\text { (KW) }\end{array}$ & $\begin{array}{l}\text { QLoss } \\
\text { (KVAR) }\end{array}$ & VSI & $\begin{array}{l}\text { PUTILIT } \\
\text { Y } \\
(\mathrm{KW})\end{array}$ & $\begin{array}{l}\text { QUTILI } \\
\text { TY } \\
\text { (KVAR) }\end{array}$ \\
\hline 0.79106 & $\begin{array}{l}31 \\
14 \\
25\end{array}$ & $\begin{array}{c}1000 \\
750 \\
500\end{array}$ & 2250 & 69.339 & 51.6276 & 0.9176 & 1534.339 & $\begin{array}{c}2351.62 \\
3\end{array}$ \\
\hline 0.78828 & $\begin{array}{l}30 \\
25 \\
16\end{array}$ & $\begin{array}{c}1000 \\
750 \\
500\end{array}$ & 2250 & $\begin{array}{c}70.8966 \\
9\end{array}$ & 57.962 & 0.9104 & 535.890 & $\begin{array}{c}2351.96 \\
2\end{array}$ \\
\hline 0.78611 & $\begin{array}{l}29 \\
15 \\
16\end{array}$ & $\begin{array}{c}1000 \\
750 \\
500\end{array}$ & 2250 & 71.741 & 52.3996 & 0.89038 & 1536.743 & $\begin{array}{c}2352.40 \\
0\end{array}$ \\
\hline 0.77022 & $\begin{array}{c}11 \\
31 \\
4\end{array}$ & $\begin{array}{c}1000 \\
750 \\
500\end{array}$ & 2250 & 75.8641 & 54.9118 & 0.89486 & 1540.665 & $\begin{array}{c}2354.91 \\
2\end{array}$ \\
\hline 0.7644 & $\begin{array}{c}30 \\
9 \\
25\end{array}$ & $\begin{array}{c}1000 \\
750 \\
500\end{array}$ & 2250 & 77.088 & 55.8658 & 0.86670 & 1542.087 & $\begin{array}{c}2355.86 \\
6\end{array}$ \\
\hline
\end{tabular}

Table 2.4. 3DG test Results without Tuning 5 best combinations. 
Analytical approaches for Optimal Placement and sizing of Distributed generation in Power System

With Tuning

\begin{tabular}{|c|c|c|c|c|c|c|c|c|}
\hline NPI & $\begin{array}{c}\text { Bus } \\
\text { Numbe } \\
\text { r }\end{array}$ & $\begin{array}{c}\mathrm{DG} \\
(\mathrm{KW})\end{array}$ & $\begin{array}{c}\mathrm{PD}_{\mathrm{G}} \\
(\text { Total) } \\
(\mathrm{KW})\end{array}$ & $\begin{array}{l}P_{\text {Loss }} \\
(\mathrm{KW})\end{array}$ & $\begin{array}{c}\text { QLoss } \\
\text { (KVAR) }\end{array}$ & VSI & $\begin{array}{c}\text { PUTILIT } \\
\mathrm{Y} \\
(\mathrm{KW})\end{array}$ & $\begin{array}{c}\text { QUTI } \\
\text { LITY } \\
\text { (KVA } \\
\text { R) }\end{array}$ \\
\hline 0.79612 & $\begin{array}{l}31 \\
14 \\
25\end{array}$ & $\begin{array}{l}899.977 \\
678.183 \\
449.838\end{array}$ & $\begin{array}{c}2027.69 \\
9\end{array}$ & 68.4845 & 48.2754 & 0.9273 & 1755.786 & $\begin{array}{c}2348.2 \\
76\end{array}$ \\
\hline 0.78903 & $\begin{array}{l}30 \\
25 \\
16\end{array}$ & $\begin{array}{l}955.671 \\
724.049 \\
480.026\end{array}$ & 2159.98 & 69.031 & 49.207 & 0.9138 & 1624.328 & $\begin{array}{c}2349.0 \\
21\end{array}$ \\
\hline 0.78657 & $\begin{array}{l}29 \\
15 \\
16\end{array}$ & $\begin{array}{l}955.744 \\
713.188 \\
477.872\end{array}$ & $\begin{array}{c}2146.80 \\
5\end{array}$ & 70.181 & 49.479 & 0.9119 & 1638.377 & $\begin{array}{c}2349.4 \\
8\end{array}$ \\
\hline 0.77024 & $\begin{array}{c}11 \\
31 \\
4\end{array}$ & $\begin{array}{c}980 \\
731.25 \\
490\end{array}$ & 201.25 & 72.1742 & 51.4284 & 0.8987 & 1585.924 & $\begin{array}{c}2351.4 \\
28\end{array}$ \\
\hline 0.7625 & $\begin{array}{c}30 \\
9 \\
25\end{array}$ & $\begin{array}{l}931.994 \\
706.110 \\
465.997\end{array}$ & $\begin{array}{c}2104.10 \\
2\end{array}$ & 74.52 & 52.297 & 0.88297 & 18685.421 & $\begin{array}{c}2352.2 \\
98\end{array}$ \\
\hline
\end{tabular}

Table 2.5. 3 DG test Results with Tuning 5 best combinations.

\begin{tabular}{|c|c|}
\hline Bus Number & $\begin{array}{c}\text { Voltage } \\
\text { (p.u) }\end{array}$ \\
\hline 1 & 1.0000 \\
\hline 2 & 0.9995 \\
\hline 3 & 0.9980 \\
\hline 4 & 0.9974 \\
\hline 5 & 0.9971 \\
\hline 6 & 0.9942 \\
\hline 7 & 0.9918 \\
\hline 8 & 0.9871 \\
\hline 9 & 0.9861 \\
\hline 10 & 0.9874 \\
\hline 11 & 0.9858 \\
\hline 12 & 0.9861 \\
\hline 13 & 0.9874 \\
\hline 14 & 0.9879 \\
\hline 15 & 0.9865 \\
\hline 16 & 0.9859 \\
\hline 17 & 0.9840 \\
\hline 18 & 0.9835 \\
\hline 19 & 0.9989 \\
\hline 20 & 0.9954 \\
\hline 21 & 0.9947 \\
\hline 22 & 0.9940 \\
\hline 23 & 0.9959 \\
\hline 24 & 0.9922 \\
\hline 25 & 0.9918 \\
\hline 26 & 0.9936 \\
\hline 27 & 0.9930 \\
\hline 28 & 0.9889 \\
\hline 29 & 0.9863 \\
\hline 30 & 0.9862 \\
\hline 31 & 0.9884 \\
\hline
\end{tabular}




\begin{tabular}{|l|l|}
\hline 32 & 0.9876 \\
\hline 33 & 0.9873 \\
\hline
\end{tabular}

Table2.6 Voltage Profile with 3DGs at bus 31, 14, 25

\section{DG Case}

The Following table represents the IVD, IVR values for best combination.

\begin{tabular}{|c|c|}
\hline IVD & IVR \\
\hline 0.9949 & 0.9852 \\
\hline
\end{tabular}

\begin{tabular}{|c|c|c|c|c|c|c|c|c|}
\hline NPI & $\begin{array}{c}\text { Bus } \\
\text { Number }\end{array}$ & $\begin{array}{l}\text { PDG } \\
(\mathrm{KW})\end{array}$ & $\begin{array}{c}\text { PDG } \\
\text { (Total) } \\
(\mathrm{KW})\end{array}$ & $\begin{array}{c}\mathrm{P}_{\text {Loss }} \\
(\mathrm{KW})\end{array}$ & $\begin{array}{c}\text { Q Loss } \\
\text { (KVAR) }\end{array}$ & VSI & $\begin{array}{c}\text { PUTILITY } \\
(\mathrm{KW})\end{array}$ & $\begin{array}{l}\text { QUTLITY } \\
\text { (KVAR) }\end{array}$ \\
\hline 0.7877 & $\begin{array}{c}24 \\
18 \\
33 \\
8 \\
9\end{array}$ & $\begin{array}{c}1000 \\
250 \\
750 \\
300 \\
500\end{array}$ & 2800 & 74.9616 & 51.5129 & 0.91643 & 989.9644 & 2351.515 \\
\hline 0.7847 & $\begin{array}{c}32 \\
25 \\
2 \\
15 \\
12\end{array}$ & $\begin{array}{c}1000 \\
250 \\
750 \\
300 \\
500\end{array}$ & 2800 & 75.2615 & 53.1826 & 0.91241 & 990.262 & 2335.184 \\
\hline 0.7761 & $\begin{array}{c}3 \\
12 \\
13 \\
32 \\
31\end{array}$ & $\begin{array}{c}1000 \\
250 \\
750 \\
300 \\
500\end{array}$ & 2800 & 78.5738 & 78.5738 & 54.9075 & 0.89104 & 2354.902 \\
\hline 0.7664 & $\begin{array}{l}30 \\
25 \\
14 \\
27 \\
21 \\
\end{array}$ & $\begin{array}{c}1000 \\
250 \\
750 \\
300 \\
500\end{array}$ & 2800 & 86.984 & 86.984 & 60.672 & 0.88 .632 & 2360.675 \\
\hline
\end{tabular}

Table. 2.7. 5DG Test Results without tuning 5 best combinations

\begin{tabular}{|c|c|c|c|c|c|c|c|c|}
\hline NPI & $\begin{array}{c}\text { Bus } \\
\text { Number }\end{array}$ & $\begin{array}{l}\mathrm{PDG} \\
(\mathrm{KW})\end{array}$ & $\begin{array}{c}\mathrm{PDG}_{\mathrm{DG}} \\
\text { (Total) } \\
(\mathrm{KW})\end{array}$ & $\begin{array}{c}\mathrm{P}_{\text {Loss }} \\
(\mathrm{KW})\end{array}$ & $\begin{array}{c}\text { Q Loss } \\
\text { (KVAR) }\end{array}$ & VSI & $\begin{array}{c}\text { PUTILITY } \\
(\mathrm{KW})\end{array}$ & \begin{tabular}{|c|} 
QUTLITY \\
(KVAR)
\end{tabular} \\
\hline 0.79027 & $\begin{array}{c}24 \\
18 \\
33 \\
8 \\
9\end{array}$ & $\begin{array}{l}868.4808 \\
222.6871 \\
671.4525 \\
264.5321 \\
438.6601\end{array}$ & 2465.813 & 687794 & 47.6779 & 0.92094 & 1317.967 & 2374.678 \\
\hline 0.78721 & $\begin{array}{c}32 \\
25 \\
2 \\
15 \\
12\end{array}$ & $\begin{array}{l}922.604 \\
324.181 \\
695.465 \\
279.598 \\
461.302\end{array}$ & 2593.151 & 71.703 & 50.63 & 0.91868 & 1193.553 & 2350.631 \\
\hline 0.7772 & $\begin{array}{c}3 \\
12 \\
13 \\
32 \\
31\end{array}$ & $\begin{array}{l}940.3366 \\
237.7294 \\
709.5862 \\
283.8345 \\
477.8723\end{array}$ & 2650.359 & 71.9391 & 50.8451 & 0.908348 & 1136.580 & 2350.845 \\
\hline 0.77432 & $\begin{array}{l}30 \\
25\end{array}$ & $\begin{array}{c}821.808 \\
206.4949\end{array}$ & 2287.264 & 72.488 & 51.145 & 0.91399 & 1500.224 & 2351.145 \\
\hline
\end{tabular}




\begin{tabular}{|l|l|l|l|l|l|l|l|l|}
\hline & 14 & 603.998 & & & & & & \\
& 27 & 244.058 & & & & & & \\
\hline
\end{tabular}

Table. 2.8. 5DG Test Results with tuning 5 best combinations

\begin{tabular}{|c|c|}
\hline Bus Number & $\begin{array}{c}\text { Voltage } \\
\text { (p.u) }\end{array}$ \\
\hline 1 & 1.0000 \\
\hline 2 & 1.0001 \\
\hline 3 & 0.9989 \\
\hline 4 & 0.9996 \\
\hline 5 & 1.0007 \\
\hline 6 & 1.0009 \\
\hline 7 & 0.9985 \\
\hline 8 & 0.9939 \\
\hline 9 & 0.9929 \\
\hline 10 & 0.9924 \\
\hline 11 & 0.9925 \\
\hline 12 & 0.9929 \\
\hline 13 & 0.9941 \\
\hline 14 & 0.9946 \\
\hline 15 & 0.9933 \\
\hline 16 & 0.9927 \\
\hline 17 & 0.9908 \\
\hline 18 & 0.9902 \\
\hline 19 & 1.0001 \\
\hline 20 & 1.0012 \\
\hline 21 & 0.0018 \\
\hline 22 & 1.0012 \\
\hline 23 & 0.9961 \\
\hline 24 & 0.9910 \\
\hline 25 & 0.9891 \\
\hline 26 & 1.0007 \\
\hline 27 & 1.0006 \\
\hline 28 & 0.9966 \\
\hline 29 & 0.9940 \\
\hline 30 & 0.9939 \\
\hline 31 & 0.9900 \\
\hline 32 & 0.9892 \\
\hline 33 & 0.9889 \\
\hline
\end{tabular}

Table2.9 Voltage Profile with 3DGs at bus 24,18,33,8,9

In table 2, the base system load data, losses, voltage, voltage stability index and utility generated real and reactive power are given. The base case voltage profile and corresponding voltage profile plot are in table 2.1 and fig. 3 , the single DG case results are given for best five combinations in NPI priority order. This is the case in which the user wants to connect single DG unit to utility in order to reduce loss and to improve voltage profile and voltage stability index of the distribution system. The voltage improvement and voltage profile plot with this case is shown in table 2.4 and fig. 4 .

In the table 2.4, the 3DG case results are given for best five best combinations in NPI priority order. This is the case in which the user wants to connect 3DG with market available DG capacities to utility in order to reduce loss and to improve voltage profile, voltage stability index and hence the NPI of the distribution system from the previous single DG case. The voltage improvement and voltage profile plot with this case is shown in table 2.6 and table 2.5, represents the $3 \mathrm{DG}$ case results for five best combinations with tuning of market available DG sizes, which results reduction in losses, improvement in voltage stability index and hence NPI of Distribution system from case of fixed DG capacities. 
Similarly in the 5DG case results are given for best five combinations are given in the tables 2.7 and 2.8 with market available DGs and with tuning of market available DGs. These cases results reduction in losses improvement in voltage profile, voltage stability index of system and hence NPI.

\section{CONCLUSION}

This work present a method of combining a new and fast power flow and genetic algorithms with an aim to provide a means of finding the combination of sites within a distribution network for connecting a predefined number of DGs. The network performance index is used in finding best combination of sites within network. In doing so it evaluates the distribution system performance with DG capacities and maximizes the Network Performance index. Voltage stability index is used to determine the weak branches in the distribution network. Its use world be to enable Distribution System Planner to search a network for the best sites to strategically connect a small number of DGs among a large number of potential combinations in order to improve Distribution system performance.

This work concentrated on the technical constraints on DG development like voltage limits, thermal limits and especially the loss reduction (DG impacts on losses is an area that is being extensively researched at present).

This work can be easily being adapted to cope with variable energy sources.

\section{REFERENCES}

[1] H. B. Puttgen, P. R. Mac Gergor, F. C. Lambert, "Distributed generation: Semantic hype or the dawn of a new era?", power \& Energy Magazine, IEEE, Vol.1, Issue. 1, pp.22-29, 2003

[2] W. EI-Khattam, M.M.A. Salama, "Distributed generation technologies definitions and benefits, Electric Power Systems Research, vol.71, issue 2, pp. 119-128, October 2004.

[3] Thomas Ackermann, Goran Andersson, Lennart Soder, "Distributed generation: a definition”, Electric power system research, vol. 57 Issue 3, pp. 195-204-20 April 2001.

[4] J.L. Del Monaco, "The role of distributed generation in the critical electric power infrastructure", power engineering society winter meeting, 2001, IEEE, vol. 1, pp. 144-145,2001.

[5] Xu. Ding, A.A. Girgis, "Optimal load shedding strategy in power systems with distributed generation", Power engineering Society Winter Meeting, 2001, IEEE vol.2, pp, $788-793,2001$.

[6] N.S. Rau and Yih Heui Wan, "Optimum Location of resources in distributed planning", IEEE Transactions on Power Systems, vol. 9, issue. 4, pp. 2014- 2020, 1994.

[7] J.O. Kim, S.W. Nam, S. K. Park, C. Singh, “ Dispersed generation planning using improved Hereford ranch algorithm”, Electric Power Systems Research, vol. 47, issue 1, pp. 47-55, October 1998.

[8] T. Griffin, K. Tomsovic, D. Secrest, A. Law, “ Placement of dispersed generation systems for reduced losses”, Proceedings of the $33^{\text {rd }}$ Annual Hawaii International Conference on System Science, 2000, IEEE, Jan 2000.

[9] K. Nara, Y. Hayashi, K. Ikeda, T. Ashizawa, "Application of tabu search to optimal placement of distributed generators", Power Engineering Society Winter Meeting, 2001, IEEE, vol. 2, pp.918 - 923, 2001.

[10] Caisheng Wang, M.H.Nehrir, " Analytical approaches for optimal placement of distributed generation sources in power systems “, IEEE Transactions on power Systems, vol. 19, issue 4, pp.2068 - 2076, 2004.

[11] T. Gozel, M. H. Hocaoglu, U. Eminoglu, A. Balikci, “ Optimal placement and sizing of distributed generation on radial feeder with different static load models", international Conference on Future Power Systems, IEEE, pp. 1-6, issue. Now. 2005.

[12] Naresh Acharya, Pukar Mahat, N. Mithulananthan, “ An analytical approach for DG allocation in primary distribution network”, Electrical Power and energy systems, vol.28 pp.669-678, feb.2006. 